\title{
PENDAMPINGAN DALAM RANCANGAN SESUAI KURIKULUM 2013 UNTUK MENINGKATKAN KUALITAS GURU-GURU SMA GITA KIRTI II JAKARTA UTARA
}

\author{
Endang Sri Rahayu \\ Universitas Negeri Jakarta \\ endang_sri_rahayu@yahoo.com \\ Siti Nurjanah \\ Universitas Negeri Jakarta \\ sitinurjanah@feunj.ac.id \\ Herlitah \\ Universitas Negeri Jakarta \\ herlitah@feunj.ac.id
}

\begin{abstract}
ABSTRAK
Kegiatan pendampingan dalam Rancangan Pembelajaran sesuai dengan kurikulum 2013 untuk meningkatkan kualitas Guru-Guru ini dilakukan di SMA Gita Kirti II Sunter Jakarta Utara sangat dibutuhkan mengingat kurikulum 2013 saat ini menjadi salah satu panduan bagi para guru didalam membuat rancangan pembelajaran. Kegiatan ini harus dilakukan dan dikembangkan secara berjangka sebagai wujud pengabdian kepada masyarakat dalam rangka peningkatan kualitas masyarakat yang pada umumnya dan pada guru pada khususnya.
\end{abstract}

Kata Kunci : Kurikulum, RPP, Standar Kompetensi

\section{PENDAHULUAN}

Analisis Situasi

Kurikulum 2013 menekankan penerapan pendekatan scientific (meliputi: mengamati, bertanya, mencoba, mengolah, menyajikan, menyimpulkan, dan mencipta untuk semua mata pelajaran) (Sudarwan, 2013). Komponen-komponen penting dalam me- ngajar menggunakan pendekatan scientific (McCollum:2009)

1) Menyajikan pembelajaran yang dapat meningkatkan rasa keingintahuan (Foster a sense of wonder),

2) Meningkatkan keterampilan meng amati (Encourage observation),

3) Melakukan analisis (Push for analysis) dan 
4) Berkomunikasi (Require communication).

Komponen tersebut sebenarnya tidak terlalu berbeda dengan kurikulum yang selama ini dilaksanakan (KTSP) akan tetapi sesuai dengan perkembangan dan tuntutan yang ada perlu adanya perubahan dalam pemahaman dari para guru, sehingga memudahkan untuk menerima perubahan tersebut. Perubahan dalam proses pembelajaran kurikulum 2013 mencakup: (a) berorientasi pada karakteristik kompetensi yang mencakup: sikap, ketrampilan dan pengetahuan.

Seperti kita ketahui sejak digulirkan kurikulum 2013, menimbulkan berbagai kendala dan menimbulkan polemik dan gejolak diantara para pelaksana di lapangan yaitu para guru dan kepala sekolah. Dari hasil pengamatan hal ini dapat terjadi karena beberapa faktor yang menjadi penyebabnya antara lain: (1) kurangnya pahaman tentang konsep perubahan itu sendiri, (2) kurang memahami tugas guru sebagai profesional, (3) sulit untuk mengembangkan atau sudah berada dalam zona nyaman, (4) merasa mendapatkan tugas tambahan, yang menjadikan perubahan menjadi suatu beban, (5) kurangnya sosialisasi dari pihak sekolah atau pemerintah, terutama untuk sekolah swasta.

Untuk dapat melaksanakan pembelajaran sesuai Kurikulum 2013, maka pemahaman tentang penyusunan dan pelaksanaan perangkat pembelajaran yang meliputi antara lain penyusunan : (1) RPP, (2) Media pembelajaran, (3) Lembar Aktivitas
Siswa/Lembar Kerja Siswa dan (4) Penilaian hasil belajar siswa.

Berdasarkan uraian tersebut maka perlu diadakan pendampingan dalam rangka penyusunan perangkat pembelajaran untuk guru-guru di SMA GIKI II, sekolah ini merupakan sekolah swasta yang letaknya cukup strategis, ditengah kota dan di pinggir jalan. Telah memiliki gedung dan sarana yang cukup memadai dan sudah terakreditasi, akan tetapi masih memerlukan bantuan untuk peningkatan kualitas para gurunya.

\section{Tujuan}

1. Memberikan pengetahuan dan kemampuan dalam memahami secara konsep dan penerapan kurikulum 2013

2. Membantu para guru memberikan keterampilan menyusun perencanaan pembelajaran yang benar

3. Membantu para guru menyiapkan media pembelajaran yang kreatif

4. Meningkatkan profesional guru.

\section{Manfaat}

Manfaat yang diperoleh atas kegiatan ini adalah:

a. Peserta kegiatan :

1. guru memiliki pemahaman yang utuh dalam menyusun rencana pembelajaran 2013

2. mampu mengembangkan rencana pembelajaran sesuai dengan kebutuhan dan karakteristik siswa.

3. memberikan bahan inovasi pembelajaran misalnya dalam hal model-model pembelajaran, penilai- 
an, penelitian tindakan kelas, dan hal-hal lain yang berkaitan dengan peningkatan pemebelajaran di kelas.

4. Mampu membuat media pembelajaran yang kreatif melalui powerpoint

b. Tim Pengabdian Masyarakat:

Memberikan kontribusi pengetahuan kepada para guru dalam rangka meningkatkan kualitas para guru sesuai dengan pengetahuan dan pengalaman yang dimiliki instruktur.

\section{KAJIAN TEORITIK Silabus}

Silabus adalah rencana pembelajaran pada suatu dan/atau kelompok mata pelajaran/tema tertentu yang mencakup standar kompetensi, kompetensi dasar, materi pokok/ pembelajaran, kegiatan pembelajaran, indikator pencapaian kompetensi untuk penilaian, penialaian, alokasi waktu, dan sumber belajar.

a. Silabus harus menjawab:

1) Kompetensi apa yang harus dikuasai siswa

2) Bagaimana cara mencapainya

3) Bagaimana mengetahui pencapaiannya

b. Prinsip-prinsip Pengembangan

1) Ilmiah

2) Relevan

3) Sistematis

4) Konsisten

5) Memadai

6) Aktual dan kontekstual

7) Fleksibel
8) Menyeluruh

c. Unit Waktu :

1) Silabus mata pelajaran disusun berdasarkan seluruh alokasi waktu yang disediakanuntuk mata pelajaran selama penyelenggaraan pendidikan di tingkat satuan pendidikan

2) Penyusunan silabus memperhatikan alokasi waktu yang disediakan per semester, per tahun dan alokasi waktu mata pelajran lain yang sekelompok

3) Implementasi pembelajaran persemester menggunakan penggalan silabus sesuai dengan SK dan KD untuk mata pelajaran dengan alokasi waktu yang tersedia pada struktur kurikulum. Bagi SMK/MAK menggunakan penggalan silabus berdasarkan satuan kompetensi

d. Pengembangan Silabus

1) Guru kelas/mata pelajaran

2) Kelompok guru kelas/mata pelajaran atau

3) Kelompok kerja guru (KKG/PKG/MGMP)

e. Komponen Silabus:

1) Standar Kompetensi

2) Kompetensi dasar

3) Materi Pokok/Pembelajaran

4) Kegiatan Pembelajaran

5) Indikator (dikembangkan berdasarkan KD)

6) Alokasi waktu

7) Sumber Belajar

f. Langkah-langkah Pengembangan

1) Mengkaji dan menentukan Standar Kompetensi 
2) Mengkaji dan menetukan Kompetensi Dasar

3) Mengidentifikasi materi pokok /Pembelajaran

4) Mengembangkan kegiatan pembelajaran

5) Merumuskan indikator pencapaian Kompetensi

6) Menentukan jenis penilaian

7) Menentukan alokasi waktu

8) Menentukan sumber belajar

Ad 1) Mengkaji Standar Kompetensi, dengan memperhatikan halhal berikut:

a. urutan berdasarkan hierarki konsep disiplin ilmu dan/atau tingkat kesulitan materi, tidak harus selalu sesuai dengan urutan yang ada di SI.

b. Keterkaitan antar standar kompetensi dan kompetensi dasar dalam mata pelajaran

c. Keterkaitan standar kompetensi dan kompetensi dasar antar mata pelajaran

Ad 2) Mengkaji Kompetensi Dasar, dengan memperhatikan hal-hal berikut:

a. urutan berdasarkan hierarki konsep disiplin ilmu dan/atau tingkat kesulitan materi, tidak harus selalu sesuai dengan urutan yang ada di SI.

b. Keterkaitan antar standar kompetensi dan kompetensi dasar dalam mata pelajaran.

c. Keterkaitan standar kompetensi dan kompetensi dasar antar mata pelajaran
Ad 3) Mengidentifikasi Materi Pokok Pembelajaran, dengan mempertimbangkan:

a. Potensi peserta siswa

b. Relevensi dengan karakteristik daerah

c. Tingkat perkembangan fisik, intelektual, emosional, sosial, dan spiritual peserta didik

d. Kebermanfaatan bagi peserta

e. Struktur keilmuan

f. Aktualitas, kedalaman dan kekuasaan materi pembelajaran

g. Relevansi dengan kebutuhan pesertadidik dan tuntutan lingkungan

h. Alokasi waktu.

Ad 4) Mengembangkan Kegiatan

Pembelajaran

a. Dirancang untuk memberi pengalaman belajar yang melibatkan mental dan fifik melalui interaksi antar peserta didik, peserta didsik dengan guru, lingkungan dan sumber belajar lainnya dalam rangka pencapaiaan kompetensi.

b. Pengalaman belajar yang dimaksud dapat terwujud melalui pendekatan pembelajaran yang bervariasi dan berpusat pada peserta didik

c. Pengalaman belajar memuat kecakapan hidup yang perlu dikuasai peserta didik.

Hal-hal yang harus diperhatikan:

a. Memberi bantuan agar dapat melaksanakan proses pembelajaran secara profesional

b. Membuat rangkaian kegiatan yang harus dilakukan peserta didik 
secara berurutan untuk mencapai kompetensi dasar.

c. Penentuan urutan kegiatan pembelajaran harus sesuai dengan hierarkhi konsep materi pembelajaran

d. Rumusan pernyataan dalam kegiatan pembelajaran minimal mengandung dua unsur penciri yang mencerminkan pengelolaan pengalaman belajar peserta didik yaitu kegiatan siswa dan materi.

\section{Pendekatan Saintifik Pada Kurikulum 2013}

Proses pembelajaran dapat dipadankan dengan suatu proses ilmiah, karena itu KR 2013 mengamanatkan esensi pendekatan saintifik dalam pembelajaran. Penalaran deduktif melihat fenomena umum untuk kemudian menarik kesimpulan yang spesifik. Sebaliknya penalaran induktif menempatkan bukti-bukti spesifik ke dalam relasi ide yang lebih luas.

Metode ilmiah umumnya menempatkan fenomenaunik dengan kajian spesifik dan detail untuk kemudian merumuskan simpulan umum. Untuk dapat disebut ilmiah, metode pencarian (method of inquiry) itu harus berbasis pada bukti-bukti dari obyek yang dapat diobservasi, empiris, dan terukur dengan prinsipprinsip penalaran yang spesifik. Karena itu metode ilmiah umumnya memuat serangkaian aktivitas pengumpulan data melalui observasi atau eksperimen,mengolah informasi atau data, menganalisa, kemudian memformulasi, dan menguji hipotesis.

\section{Teori psikologi dalam pembelajaran}

Nana Syaodih Sukmadinata (1997) mengemukakan bahwa minimal terdapat dua bidang psikologi yang mendasari pengembangan kurikulum yaitu (1) psikologi perkembangan dan (2) psikologi belajar. Psikologi perkembangan merupakan ilmu yang mempelajari tentang perilaku individu berkenaan dengan perkembangannya. Dalam psikologi perkembangan dikaji tentang hakekat perkembangan, pentahapan perkembangan, aspekaspek perkembangan, tugas-tugas perkembangan individu, serta hal-hal lainnya yang berhubungan perkembangan individu, yang semuanya dapat dijadikan sebagai bahan pertimbangan dan mendasari pengembangan kurikulum. Psikologi belajar merupakan ilmu yang mempelajari tentang perilaku individu dalam konteks belajar.

$$
\text { Psikologi belajar mengkaji }
$$

tentang hakekat belajar dan teori-teori belajar, serta berbagai aspek perilaku individu lainnya dalam belajar yang semuanya dapat dijadikan sebagai bahan pertimbangan sekaligus mendasari pengembangan kurikulum. Dengan mengutip pemikiran Spencer, Ella Yulaelawati mengemukakan pengertian kompetensi bahwa kompetensi merupakan "karakteristik mendasar dari seseorang yang merupakan hubungan kausal dengan referensi kriteria yang efektif dan atau penampilan yang terbaik dalam pekerjaan pada suatu situasi". 
Selanjutnya, dikemukakan pula tentang 5 tipe kompetensi, yaitu:

a. Motif; sesuatu yang dimiliki seseorang untuk berfikir secara konsisten atau keinginan untuk melakukan suatu aksi.

b. Bawaan; yaitu karakteristik fisik yang merespons secara konsisten berbagai situasi atau informasi.

c. Konsep diri; yaitu tingkah laku, nilai atau image seseorang.

d. Pengetahuan; yaitu informasi khusus yang dimiliki seseorang;

e. Keterampilan; yaitu kemampuan melakukan tugas secara fisik maupun mental.

Kelima kompetensi tersebut mempunyai implikasi praktis terhadap perencanaan sumber daya manusia atau pendidikan. Keterampilan dan pengetahuan cenderung lebih tampak pada permukaan ciri-ciri seseorang, sedangkan konsep diri, bawaan dan motif lebih tersembunyi dan lebih mendalam serta merupakan pusat kepribadian seseorang. Kompetensi permukaan (pengetahuan dan keterampilan) lebih mudah dikembangkan, pelatihan merupakan hal tepat untuk menjamin kemampuan ini.

\section{Teori Belajar Konstruktivisme Vygotsky}

Vygotsky (1925) menekankan pentingnya memanfaatkan lingkungan dalam pembelajaran. Lingkungan sekitar siswa meliputi orang-orang, kebudayaan, termasuk pengalaman dalam lingkungan tersebut. Orang lain merupakan bagian dari lingkungan (Taylor, 1993), perolehan pengetahuan siswa bermula dari lingkup sosial, antar orang, dan kemudian pada lingkup individu sebagai peristiwa internalisasi (Taylor, 1993). Vygotsky menekankan pada pentingnya hubungan antara individu dan lingkungan sosial dalam pembentukan pengetahuan yang menurut beliau, bahwa interaksi sosial yaitu interaksi individu tersebut dengan orang lain merupakan faktor terpenting yang dapat memicu perkembangan kognitif seseorang. Vygotsky berpendapat bahwa proses belajar akan terjadi secara evisien dan efektif apabila anak belajar secara kooperatif dengan anakanak lain dalam suasana dan lingkungan yang mendukung (supportive), dalam bimbingan seseorang yang lebih mampu, guru atau orang dewasa. Dengan hadirnya teori konstruktivisme Vygotsky ini, banyak pemerhati pendidikan yang mengembangkan model pembelajaran kooperatif, model pembelajaran peer interaction, model pembelajaran kelompok, dan model pembelajaran problem poshing.

Berkaitan dengan pembelajaran, Vygotsky mengemukakan empat prinsip seperti yang dikutip oleh (Slavin, 2000: 256) yaitu:

1. Pembelajaran sosial (social leaning). Pendekatan pembelajaran yang dipandang sesuai adalah pembelajaran kooperatif. Vygotsky menyatakan bahwa siswa belajar melalui interaksi bersama dengan orang dewasa atau teman yang lebih cakap; 
2. ZPD (zone of proximal development). Bahwa siswa akan dapat mempelajari konsep-konsep dengan baik jika berada dalam ZPD. Siswa bekerja dalam ZPD jika siswa tidak dapat memecahkan masalah sendiri, tetapi dapat memecahkan masalah itu setelah mendapat bantuan orang dewasa atau temannya (peer); Bantuan atau support dimaksud agar si anak mampu untuk mengerjakan tugas-tugas atau soalsoal yang lebih tinggi tingkat kerumitannya dari pada tingkat perkembangan kognitif si anak.

3. Masa Magang Kognitif (cognitif apprenticeship). Suatu proses yang menjadikan siswa sedikit demi sedikit memperoleh kecakapan intelektual melalui interaksi dengan orang yang lebih ahli, orang dewasa, atau teman yang lebih pandai;

4. Pembelajaran Termediasi (mediated learning). Vygostky menekankan pada scaffolding. Siswa diberi masalah yang kompleks, sulit, dan realistik, dan kemudian diberi bantuan secukupnya dalam memecahkan masalah siswa.

Inti teori Vigotsky adalah menekankan interaksi antara aspek internal dan eksternal dari pembelajaran dan penekanannya pada lingkungan sosial pembelajaran. Menurut teori Vigotsky, fungsi kognitif manusia berasal dari interaksi social masing-masing individu dalam konteks budaya. Vigotsky juga yakin bahwa pembelajaran terjadi saat siswa bekerja menangani tugas-tugas yang belum dipelajari namun tugas-tugas tersebut masih dalam jangkauan kemampuannya atau tugas-tugas itu berada dalam zona of proximal development mereka.

Beberapa hal yang mendapat perhatian pembelajaran konstruktivistik, yaitu:

1. mengutamakan pembelajaran yang bersifat nyata dalam konteks yang relevan.

2. mengutamakan proses,

3. menanamkan pembelajran dalam konteks pengalaman social,

4. pembelajaran dilakukan dalam upaya mengkonstruksi pengalaman

\section{Teori Inovasi}

Pada umumnya para pakar sependapat bahwa proses inovasi itu memerlukan adanya akumulasi pengetahuan

Hal yang berhubungan dengan inovasi (pembaharuan) berkaitan erat pada istilah invention dan discovery. Invention adalah penemuan sesuatu yang benar-benar baru artinya hasil karya manuasia. Discovery adalah penemuan sesuatu (benda yang sebenarnya telah ada sebelumnya. Dengan demikian, inovasi dapat diartikan usaha menemukan benda yang baru dengan jalan melakukan kegiatan (usaha) invention dan discovery. Dalam kaitan ini Ibrahim (1989) mengatakan bahwa inovasi adalah penemuan yang dapat berupa sesuatu ide, barang, kejadian, metode yang diamati sebagai sesuatu hal yang baru bagi seseorang atau sekelompok orang (masyarakat). Inovasi dapat 
berupa hasil dari invention atau discovery. Inovasi dilakukan dengan tujuan tertentu atau untuk memecahkan masalah (Subandiyah 1992:80) Proses dan tahapan perubahan itu ada kaitannya dengan masalah pengembangan (development), penyebaran (diffusion), diseminasi (dissemination), perencanaan (planning), adopsi (adoption), penerapan (implementation) dan evaluasi (evaluation) (Subandiyah 1992:77)

\section{Perubahan dan Inovasi Pendidikan}

Pelaksanaaan inovasi pendidikan seperti inovasi kurikulum tidak dapat dipisahkan dari inovator dan pelaksana inovasi itu sendiri. Inovasi pendidikan seperti yang dilakukan di Depdiknas yang disponsori oleh lembaga-lembaga asing cenderung merupakan "Top-Down Inovation".

Inovasi ini sengaja diciptakan oleh atasan sebagai usaha untuk meningkatkan mutu pendidikan atau pemerataan kesempatan untuk memperoleh pendidikan, ataupun sebagai usaha untuk meningkatkan efisiensi dan sebaginya. Inovasi seperti ini dilakukan dan diterapkan kepada bawahan dengan cara mengajak, menganjurkan dan bahkan memaksakan apa yang menurut pencipta itu baik untuk kepentingan bawahannya. Dan bawahan tidak punya otoritas untuk menolak pelaksanaannya. Ada inovasi yang juga dilakukan oleh guruguru, yang disebut dengan "Bottom-Up Innovation". Model yang kedua ini jarang dilakukan di Indonesia selama ini karena sitem pendidikan yang sentralistis.

Pembahasan tentang model inovasi seperti model "Top-Down" dan "Bottom-Up" telah banyak dilakukan oleh para peneliti dan para ahli pendidikan. Sudah banyak pembahasan tentang inovasi pendidikan yang dilakukan misalnya perubahan kurikulum dan proses belajar mengajar.

White (1988: 136-156) misalnya menguraikan beberapa aspek yang bekaitan dengan inovasi seperti tahapan-tahapan dalam inovasi, karakteristik inovasi, manajemen inovasi dan sistem pendekatannya. Kennedy (1987:163) juga membicarakan tentang strategi inovasi yang dikutip dari Chin dan Benne (1970) menyarankan tiga jenis strategi inovasi, yaitu: Power Coercive (strategi pemaksaan), Rational Empirical (empirik rasional), dan Normative-ReEducative (Pendidikan yang berulang secara normatif).

Strategi inovasi yang pertama adalah strategi pemaksaaan berdasarkan kekuasaan merupakan suatu pola inovasi yang sangat bertentangan dengan kaidah-kaidah inovasi itu sendiri. Strategi ini cenderung memaksakan kehendak, ide dan pikiran sepihak tanpa menghiraukan kondisi dan keadaan serta situasi yang sebenarnya dimana inovasi itu akan dilaksanakan. Kekuasaan memegang peranan yang sangat kuat pengaruhnya dalam menerapkan ide-ide baru dan perubahan sesuai dengan kehendak dan pikiran-pikiran dari 
pencipta inovasinya. Pihak pelaksana yang sebenarnya merupakan obyek utama dari inovasi itu sendiri sama sekali tidak dilibatkan baik dalam proses perencanaan maupun pelaksanaannya.

Para inovator hanya menganggap pelaksana sebagai obyek semata dan bukan sebagai subyek yang juga harus diperhatikan dan dilibatkansecara aktif dalam proses perencanaan dan pengimplementasiannya.

Strategi inovasi yang kedua adalah empirik Rasional. Asumsi dasar dalam strategi ini adalah bahwa manusia mampu menggunakan pikiran logisnya atau akalnya sehingga mereka akan bertindak secara rasional. Dalam kaitan dengan ini inovator bertugas mendemonstrasikan inovasinya dengan menggunakan metode yang terbaik valid untuk memberikan manfaat bagi penggunanya. Di samping itu, startegi ini didasarkan atas pandangan yang optimistik seperti apa yang dikatakan oleh Bennis, Benne, dan Chin yang dikutip dari Cece Wijaya dkk (1991). Di sekolah, para guru menciptakan strategi atau metode mengajar yang menurutnya sesuai dengan akal yang sehat, berkaitan dengan situasi dan kondisi bukan berdasarkan pengalaman guru tersebut. Di berbagai bidang, para pencipta inovasi melakukan perubahan dan inovasi untuk bidang yang ditekuninya berdasarkan pemikiran, ide, dan pengalaman dalam bidangnya itu, yang telah digeluti berbulan-bulan bahkan bertahun-tahun. Inovasi yang demikian memberi dampak yang lebih baik dari pada model inovasi yang pertama. Hal ini disebabkan oleh kesesuaian dengan kondisi nyata di tempat pelaksanaan inovasi tersebut.

Jenis strategi inovasi yang ketiga adalah normatif re-edukatif (pendidikan yang berulang) adalah suatu strategi inovasi yang didasarkan pada pemikiran para ahli pendidikan seperti Sigmund Freud, John Dewey, Kurt Lewis dan beberapa pakar lainnya (Cece Wijaya (1991), yang menekankan bagaimana klien memahami permasalahan pembaharuan seperti perubahan sikap, skill, dan nilai-nilai yang berhubungan dengan manusia.

Dalam pendidikan, sebuah strategi bila menekankan pada pemahaman pelaksana dan penerima inovasi, maka pelaksanaan inovasi dapat dilakukan berulang kali. Misalnya dalam pelaksanaan perbaikan sistem belajar mengajar di sekolah, para guru sebagai pelaksana inovasi berulang kali melaksanakan perubahan-perubahan itu sesuai dengan kaidah-kaidah pendidikan. Kecenderungan pelaksanaan model yang demikian agaknya lebih menekankan pada proses mendidik dibandingkan dengan hasil dari perubahan itu sendiri. Pendidikan yang dilaksanakan lebih mendapat porsi yang dominan sesuai dengan tujuan menurut pikiran dan rasionalitas yang dilakukan berkalikali agar semua tujuan yang sesuai dengan pikiran dan kehendak pencipta 
dan pelaksananya dapat tercapai. Para ahli mengungkapkan berbagai persepsi, pengertian, interpretasi tentang inovasi seperti Kennedy (1987), White (1987), Kouraogo (1987) memberikan berbagai macan definisi tentang inovasi yang berbeda-beda. Dalam hal ini, penulis mengutip definisi inovasi yang dikatakan oleh White (1987:211) yang berbunyi: "Inovation ......more than change, although all innovations involve change." ( inovasi itu ... lebih dari sekedar perubahan, walaupun semua inovasi melibatkan perubahan).

Untuk mengetahui dengan jelas perbedaan antara inovasi dengan perubahan, bisa dilihat dari definisi yang diungkapkan oleh Nichols (1983:4). "Change refers to " continuous reapraisal and improvement of existing practice which can be regarded as part of the normal activity ..... while innovation refers to .... Idea, subject or practice as new by an individual or individuals, which is intended to bring about improvement in relation to desired objectives, which is fundamental in nature and which is planned and deliberate."

Nichols menekankan perbedaan antara perubahan (change) dan inovasi (innovation) sebagaimana dikatakannya di atas, bahwa perubahan mengacu kepada kelangsungan penilaian, penafsiran dan pengharapan kembali dalam perbaikan pelaksanaan pendidikan yang ada yang diangap sebagai bagian aktivitas yang biasa. Sedangkan inovasi menurutnya adalah mengacu kepada ide, obyek atau praktek sesuatu yang baru oleh seseorang atau sekelompok orang yang bermaksud untuk memperbaiki tujuan yang diharapkan.

\section{METODOLOGI}

\section{Kerangka Pemecahan Masalah}

Kerangka atau tahapan dalam kegiatan sosialisai ini adalah sebagai berikut:

\section{Analisis Kebutuhan}

Berdasarkan diskusi yang dilakukan oleh tim pengabdian masyarakat pada program kegiatan ini, khususnya sekolah swasta memerlukan program kegiatan ini dengan pertimbangan:

a. Kurangnya pemahaman para guru mengenai Rancangan Pembelajaran yang sesuai kurikulum 2013.

b. Kurangnya pemahaman para guru mengenai penyajian media pembelajaran yang kreatif.

\section{Rancangan instruksional}

Dalam menentukan rancangan instruksional ini perlu dipertimbangkan aspek-aspek berikut:

a. Isi materi program kegiatan yang relevan dengan kurikulum 2013.

b. Isi materi program kegiatan sesuai kebutuhan guru mengenai media pembelajaran melalui powerpoint.

c. Latar belakang sekolah dari sekolah swasta.

\section{Tahap Pengembangan}

Dalam rangka kegiatan sosialisasi ini, tim pengabdian masyarakat berupaya mengembangkan kegiatan ini baik dalam hal 
penyampaian materi kegiatan maupun Tanya jawab atas materi yang di sampaikan.

\section{Realisasi Pemecahan Masalah}

\section{Pelaksanaan}

Pelaksanaan program kegiatan ini pada bulan September 2016 bertempat di SMA dan SMP Gita Kirti (GIKI) II Sunter Jakarta Utara. Waktu yang dialokasikan yaitu 3 jam atau kira-kira dimulai pada jam 09.00 12.00 WIB.

2. Evaluasi

Tim pengabdian Masyarakat akan menyususn evaluasi terkait dengan pemahaman peserta terhadap materi kegiatan, pelaksanaan kegiatan secara keseluruhan untuk menampung kemungkinan dibutuhkannya kegiatan dengan materi lain dan tertibnya pelaksanaan program kegiatan ini.

\section{Khalayak Sasaran}

Peserta yang hadir dalam kegiatan ini sebanyak 30 orang yaitu guru-guru SMA dan SMP Gita Kirti (GIKI) II Sunter Jakarta Utara. Kegiatan ini terkait dengan instansi seperti Universitas Negeri Jakarta yang membiayai kegiatan Pengabdian Masyarakat yang dilaksanakan oleh dosen-dosen sebagai sebuah kewajiban atas Tridharma Perguruan Tinggi serta Kepala Sekolah SMA dan SMP Gita
Kirti (GIKI) II yang memberikan izin untuk kegiatan tersebut.

\section{Metode Kegiatan}

Metode kegiatan yang digunakan diharapkan dapat memberikan kemudahan kepada peserta kegiatan. Dalam kegiatan ini, metode yang digunakan adalah Metode Penjelasan, Tanya Jawab, Diskusi, dan Praktek. Pada Metode Penjelasan, setiap instruktur menyampaikan materi terkait dengan menggunakan powerpoint dan fotocopy an contoh RPP yang dibagikan kepada peserta kegiatan. Pada Tanya jawab, peserta diberikan waktu untuk bertanya dan instruktur akan menjawab pertanyaan dari para peserta. Pada sesi Diskusi, instruktur memberikan kesempatan atau waktu untuk mendiskusikan halhal apa saja yang menjadi kendala pada saat pembuatan RPP. Dan yang terakhir untuk praktek ini dilakukan pada saat sesi materi Media Pembelajaran yang diharuskan peserta membawa Laptop dan mendownload materi yang telah diberikan oleh instruktur.

\section{Materi Kegiatan dan Instruktur Materi kegiatan yang disampaikan dan instruktur pada program kegiatan ini dijelaskan pada tabel dibawah ini.}


Tabel 1

Materi Kegiatan dan Instruktur

\begin{tabular}{c|l|l|l}
\hline No & \multicolumn{1}{|c|}{ Materi } & \multicolumn{1}{|c}{ Instruktur } & \multicolumn{1}{|c}{ Jumlah Jam } \\
\hline 1 & Pembukaan dan Sambutan & & 30 Menit \\
\hline 2 & $\begin{array}{l}\text { Rancangan Pembelajaran } \\
\text { Sesuai K-13 }\end{array}$ & Agus Wibowo, M.Pd & 60 Menit \\
\hline 3. & Media Pembelajaran & Suparno, M.Pd & 60 Menit \\
\hline & Total Alokasi Waktu & & 2 Jam 30 Menit \\
\hline
\end{tabular}

\section{HASIL DAN PEMBAHASAN \\ Deskripsi Kegiatan}

Kegiatan pendampingan dalam Rancangan Pembelajaran sesuai dengan kurikulum 2013 untuk meningkatkan kualitas Guru-Guru ini dilakukan di SMA Gita Kirti II Sunter Jakarta Utara dengan nara sumber dan dibantu oleh tim pihak sekolah.

Peserta

pelatihannya seluruhnya berjumlah 35 orang, terdiri dari Ibu dan Bapak Guru dari SMA dan SMP Gita Kirti II. Pelaksanaan kegiatan dilaksanakan di ruang pertemuan SMA GIKI II dilengkapi dengan LCD dan sound system yang disediakan dari pihak sekolah. Pelaksanaan kegiatan tersebut berjalan lancar, hal ini dikarenakan partisipasi dan keterkaitan semua pihak terutama Kepala Sekolah SMA GIKI II yang telah memberikan izin tempat serta waktunya.

Kegiatan ini dilaksanakan hari Jum'at, 16 September 2015 dari jam 09.30 sampai dengan jam 12.00 WIB. Pelaksanaan juga didukung oleh Kepala Sekolah SMP Gita Kirti II dengan mengikuti dan mengizinkan para guru untuk mengikuti kegiatan ini. Kegiatan ini ditekankan pada pemahaman para guru dalam memahami kurikulum 2013. Karena ternyata tidak semua guru membuat atau bahkan belum mengerti mengenai point-point apa saja yang harus ada pada K-13. Serta memberikan pelatihan kepada para guru tentang bagaimana cara membuat media pembelajaran yang menarik melalui slide powerpoint.

Selain itu diadakan sesi diskusi mengenai apa saja yang menjadi tantangan dan kendala dalam membuat Rancangan Pembelajaran serta perbedaan apa saja yang terdapat pada RPP K-13 Revisi. Pada saat sesi Media Pembelajaran terlebih dahulu peserta diputarkan Video para calon guru yang ada di PPG atau program SM3T, agar peserta menyadari bahwa kita harus bersyukur menjadi guru yang berada di Kota besar dipenuhi fasilitas dan membuat para peserta harus berfikir lebih kreatif lagi dalam menyajikan pembelajaran melalui media pembelajaran yang kreatif. Peserta diminta membawa laptop dan mendownload suatu aplikasi yang telah disediakan oleh nara sumber, 
yang aplikasi tersebut akan digunakan sebagai sarana untuk membuat powerpoint yang menarik.

\section{Analisis Teori}

Cara yang digunakan dalam melakukan kegiatan ini adalah dengan cara melakukan pendekatan langsung kepada peserta yaitu dengan tatap muka dan menjelaskan dengan media disertai dengan contoh-contoh yang konkrit, sehingga peserta tidak hanya melihat Rancangan pembelajaran sesuai K-13 tetapi langsung ke contohcontoh pada setiap mata pelajaran yang para peserta ampuh.

Agar materi dapat dipahami dengan baik maka tim memilih metode pemberian materi dilanjutkan dengan sesi Tanya jawab, sharing, studi kasus, dan sesi diskusi.

\section{Keterkaitan}

Kegiatan ini terkait dengan instansi seperti Universitas Negeri Jakarta yang membiayai kegiatan Pengabdian Masyarakat yang dilaksanakan oleh dosen-dosen sebagai sebuah kewajiban atas Tri Dharma Perguruan Tinggi serta Sekolah yang menjadi tempat kegiatan tersebut.

\section{KESIMPULAN DAN SARAN Kesimpulan}

Peran guru sangat penting dalam mendidik para siswa disekolah, setiap guru dituntut untuk selalu memberikan peran yang besar bagi para siswa agar mampu menerima pelajaran disekolah. Untuk tuntutan yang begitu besar ini menyebabkan atau meng- haruskan para guru untuk mengikuti segala bentuk peraturan yang ada dari pembuat kebijakan untuk peningkatan kualitas pendidikan di Indonesia.

Proses pembelajaran dapat dipadankan dengan suatu proses ilmiah, karena itu KR 2013 mengamanatkan esensi pendekatan saintifik dalam pembelajaran. Penalaran deduktif melihat fenomena umum untuk kemudian menarik kesimpulan yang spesifik. Sebaliknya penalaran induktif menempatkan bukti-bukti spesifik ke dalam relasi ide yang lebih luas.

Kegiatan pengabdian masyarakat ini mempunyai tujuan 1) Untuk memberikan pengetahuan dan kemampuan dalam memahami secara konsep dan penerapan kurikulum 2013. 2) Membantu para guru memberikan keterampilan menyusun perencanaan pembelajaran yang benar. 3) Membantu para guru menyiapkan media pembelajaran yang kreatif. 4) Meningkatkan profesionalisme guru.

Hasil yang dicapai dalam kegiatan sosialisasi ini ialah peserta merasa puas dan senang terhadap kegiatan tersebut, terbukti dari data kehadiran, peserta tertib mendengarkan dan mengikuti kegiatan hingga selesai dengan jumlah yang tetap dan tidak berkurang. Peserta juga terlihat antusias dalam memberikan tanggapan dan pertanyaan kepada nara sumber yang memandu kegiatan tersebut. Dapat disimpulkan kegiatan ini sangat diminati peserta, bahkan ada yang mengusulkan untuk dapat dilaksanakan kegiatan lanjutan. 
Saran

Kegiatan ini harus dilakukan dan dikembangkan lagi secara berjangka sebagai wujud pengabdian kepada masyarakat dalam rangka peningkatan kualitas masyarakat yang pada umumnya dan pada guru pada khususnya. Dimana kami mengharapkan kepada para guru untuk terus meng-update diri agar mampu menyesuaikan perkembangan kurikulum yang ada sesuai dengan yang ditetapkan dalam hal ini Kurikulum 2013, serta lebih meningkatkan kemampuan dalam menyediakan media didalam pembelajaran agar para siswa tidak jenuh dalam menerima materi pembelajaran.

Untuk Fakultas Ekonomi diharapkan dapat melaksanakan kegiatan yang efektif dengan hasil yang optimal dan riil agar manfaatnya lebih meningkat khususnya bagi kesejahteraan masyarakat baik untuk lingkungan masyarakat maupun lingkungan sekolah. Terciptanya tujuan dan manfaat dari pengabdian masyarakat ini maka tidak terlepas dari dukungan dana yang memadai, agar kegiatan tersebut dapat dilakukan dalam jangka waktu yang lebih lama.

\section{DAFTAR PUSTAKA}

Cece Wijaya, Djaja Jajuri, A. Tabrani Rusyam (1991) Upaya Pembaharuan dalam Bidang Pendidikan dan Pengajaran.
Penerbit PT. Remaja Rosdakarya- Bandung 1991.

Day, C.P. Whitaker, and D. Wren (1987) Appraisal and Professional Development in the Primary Schools, Philadelphia : Open University Press.

Kennedy, C. (1987) Innovation for Change: teacher development and innovation. ELT Journal41/3

Kouraogo, P. (1987) Curriculum Renewal and INSET in Difficult circumstance. ELT Journal41/3

Munro. R.G. (1977) Innovation Success or Failure? Bristol: J.W. Arrowss Smith CambrideEnglishDictionary

Nicholls, R. (1983) Managing Educational Innovation.

London. George, Allen and Unwin.

Subandijah (1992) Pengembangan dan Inovasi Kurikulum. PT Raja Grafindo Persada-Yogyakarta

White, R.V. (1988) The ELT Curriculum: Design, Innovation and Management. Oxford: Blackwell.

White, R.V. (1987) Managing Innovation. ELT.Journal 41/3

Wright, T. (1987) Roles of Teachers and Learners. Oxford: Oxford University Press. 